\title{
APPLYING THE ISF TECHNOLOGY TO PRODUCE THE CAR PART MODELS
}

\author{
Phan Dinh Tuan, Nguyen Thien Binh, Le Khanh Dien, Pham Hoang Phuong \\ DCSELAB, University of Technology, VNU-HCM \\ (Manuscript Received on October $21^{\text {th }}, 2010$, Manuscript Revised January $21^{\text {st }}, 2011$ )
}

ABSTRACT: The paper presents an application the research results previously done by group on the influence of technological parameters to the deformation angle and finish surface quality in order to choose technology parameters for the incremental sheet forming (ISF) process to produce products for the purpose of rapid prototyping or single-batch production, including all steps from design and process 3D CAD model, calculate and select the technological parameters, setting up manufacturing and the stage of post-processing. The samples formed successfully showed high applicability of this technology to practical work, the complex products with the real size can be produced in industries: automotive, motorcycle, civil...

Keywords: SPIF, ISF, Single Point Incremental Forming, ISF real-parts...

\section{INTRODUCTION}

Nowadays, the production of sheet products in small quantities, but the flexibility in change of design and size is a requirement in many fields such as automotive, aviation cosmic, medicine, household appliances... Market needs of rapid prototyping products also require a technology that can meet this demand (Truong Hai Auto Company...): a technology that can perform in the short term, does not require expensive machines and equipment, the process is simple. Traditional methods used in the current industry are hard to meet this demand because the expensive cost of mold and other relating equipment. The time to build a die for complex products is quite long [5].

In recent years, the field of sheet metal deformation was studied and introduced in order to reduce costs and production time. In particular, the ISF technology with the capability of meeting the above requirements is being researched strongly [1]. Although this technology is rather new in the world due to the only investment in research for several decades recently, but it has shown its potential development. The advantage of this method is that objects with asymmetric shape can be produced without using molds, saving time and costs, can change the product flexibly. Thus, the applicability of this technology is considerable [6].

Compared to other methods of forming sheets, this method has the advantage of significantly shortening the production time. From the computer model, there are two additional processing steps conducted: producing the plastic supporter and pressing plate by using a forming tool mounted on the CNC machine... In other words, this method is 
capable of forming direct from CAD models on a computer that does not waste time and costs to produce die and punch as different methods.
Thus it is flexible when design changes, the forming tool control lines will generate automatically to fit.
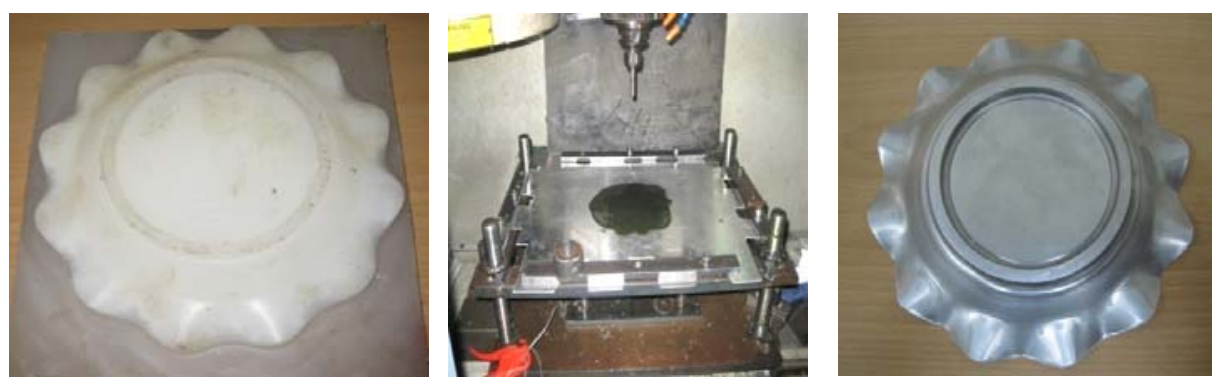

Figure 1. A sample of producing a sheet model by using ISF

With these advantages, the ISF technology will bring many benefits to many sectors: civil, industrial, medical, rapid prototyping and single - batch production... especially in the automotive industry. Therefore, the ISF technology should be invested in research to having widespread applications into actual production. The objective of this paper is to apply the previous results of research works on ISF technology at National Key Laboratory of Digital Control and System Engineering (DCSELAB) to create product models, creating the basis for the production of real parts corresponding to theirs true size and complexity [2],[3],[4].

\section{PROCESS OF SHEET PRODUCT FORMING}

A process of producing sheet products by ISF technology is suggested in the Fig. 2 [3]:

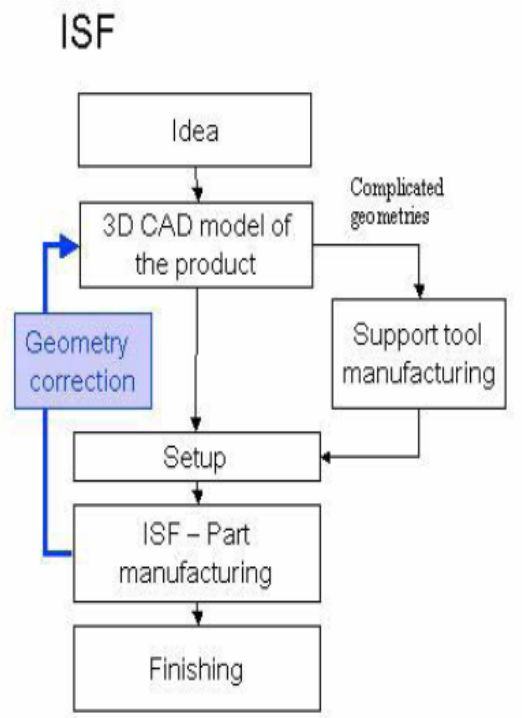

Figure 2. Diagram in producing sheet models by ISF

The detailed steps of procedure are illustrated in the diagram (Fig. 3):

\section{Trang 14}




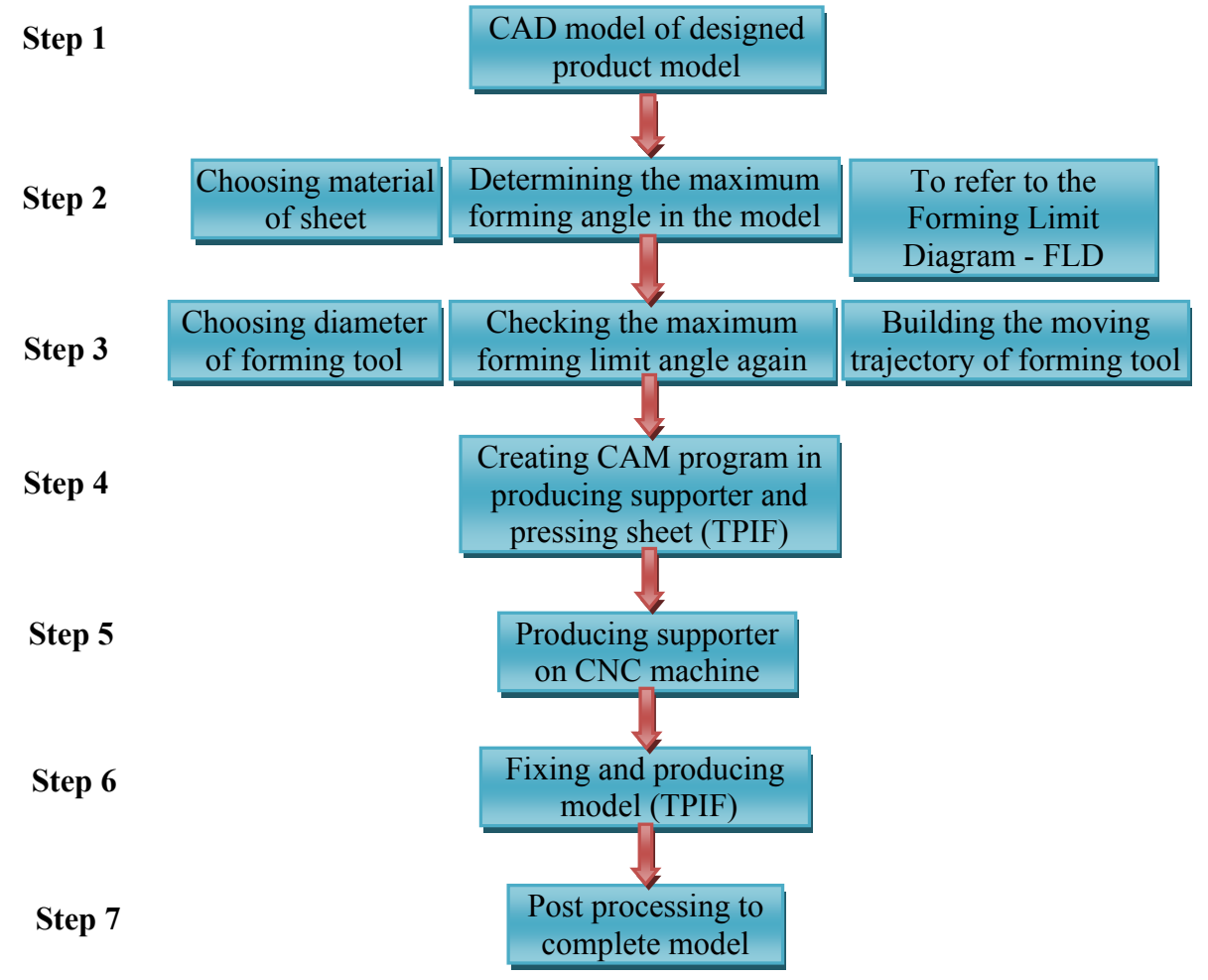

Figure 3. Steps of producing model by ISF

\section{APPLICATION METHOD FOR THE}

\section{CAR PART PROTOTYPING}

\subsection{Designing model 3D and processing}

The paper take a car model designed with Autodesk Inventor 2010 (refer to GT model of Nissan vehicles, Japan) as an example to introduce the application of this process (Fig. 4).

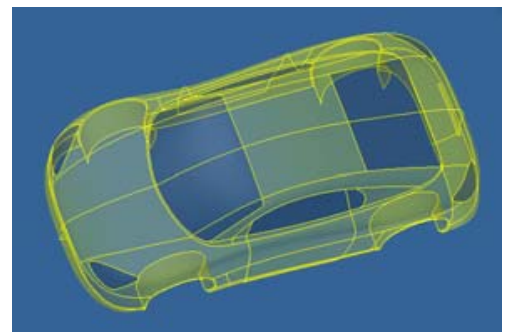

Figure 4. 3D Model designed with Autodesk Inventor
The processing model aims to ensure the largest deformation angle being less than the forming limit angle of each specific material as specified in [3], reducing the time and ensuring the technical requirements of the product.

3.2. Work piece, machine, fixture, tool, lubrication

Sheet material: Aluminum A1050-H14, $1 \mathrm{~mm}$ in thickness.

Machine: Milling machine 3 axes HASS.

Fixture: Fixture in forming TPIF includes a platform on which to attach a plate to keep the supporter and four guide bars are attached to the substrate. On the four bars, the clamping plate slide up and down. The structure of a TPIF fixture is shown in Fig. 5. 

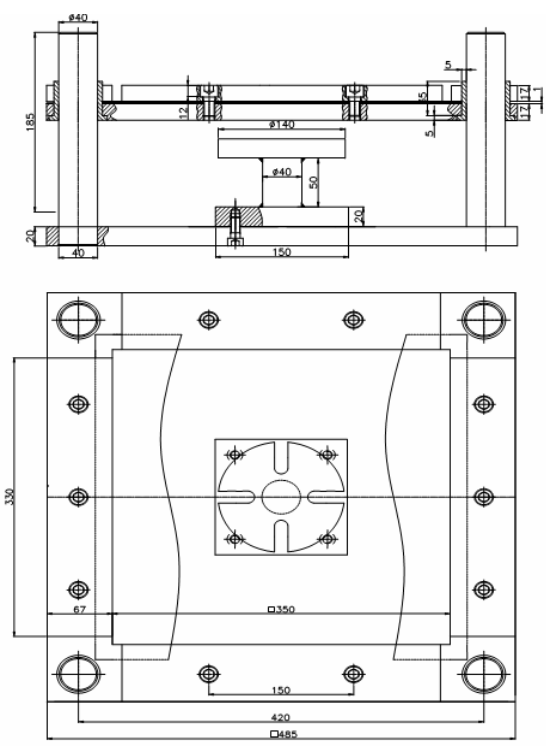

Figure 5. Fixture

Lubrication: Engine oil - grease mixture, ratio 3:1. Lubrication appears to be an important factor in sheet metal forming. It reduces friction at the tool-work-piece interface and improves surface quality.

The forming tool: High speed steel sphere-tip tool with $5 \mathrm{~mm}$ and $10 \mathrm{~mm}$ diameter (Fig. 6).
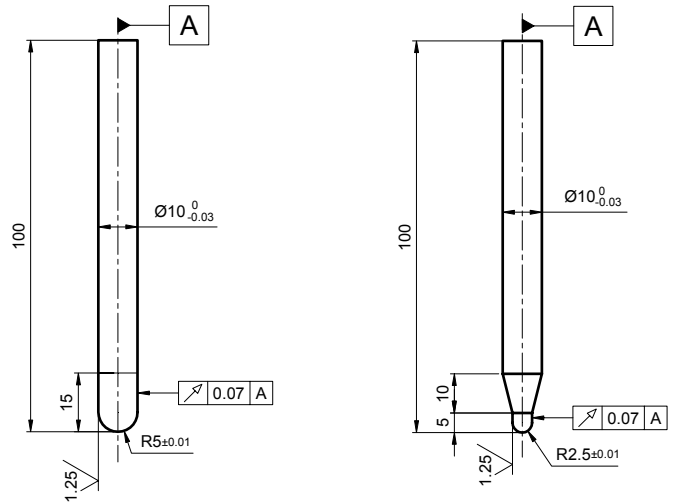

Figure 6. The forming tool

\subsection{Producing plastic supporter}

The selection process for producing plastic supporter based on:

- Technological parameters about processing characteristics of plastics used as the supporter provided by the manufacturer: the melting temperature, the highest cutting speed that the heat generated during the cutting process does not melt plastic, the strength of plastic material...

- The processing capability of 3 -axis CNC milling machine used for processing.

- Requirements to shorten the time when producing supporter in order to increase productivity and reduce costs of machine.

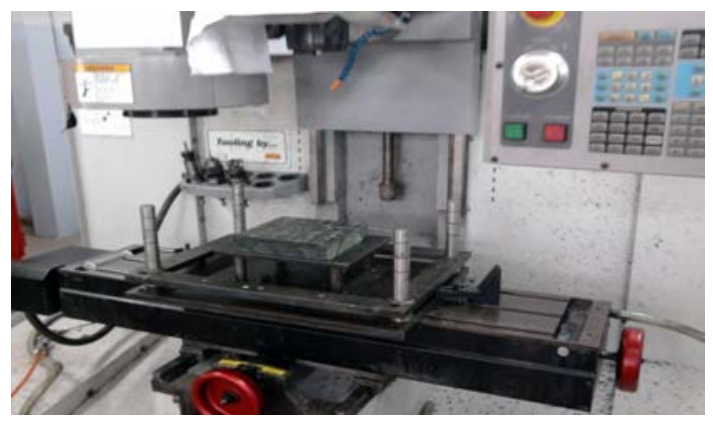

Figure 7. Fixture and work-piece fixed on machine table

The Fig. $7 \& 8$ show a wok-piece fixture and a supporter of car part after producing:

\section{Trang 16}




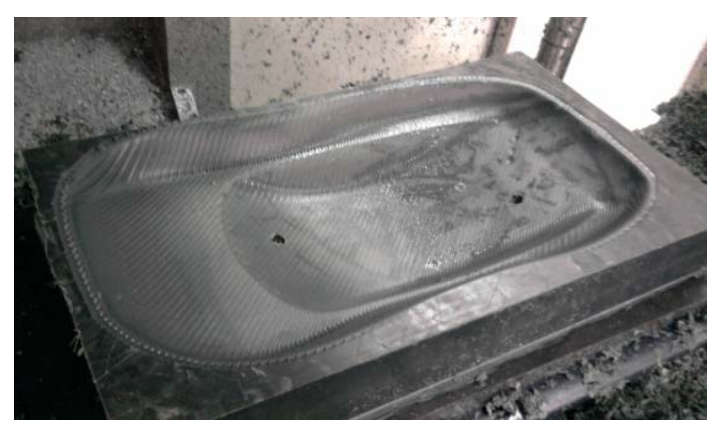

Figure 8. Supporter of car's dome

\subsection{Pressing sheet using $\mathrm{CNC}$ machine}

To reduce the effect of forming force in the $\mathrm{z}$ direction, set up wall angle parameter of down line compared with horizontal by $5^{0}$.
Producing modes by TPIF technology for each component of the model are chosen according to the results researched in [5], as follows:

Table 1. Choosing the producing parameters [5]

\begin{tabular}{lcccccc}
\hline Parts & $\begin{array}{c}\mathbf{n} \\
(\mathbf{r p m})\end{array}$ & $\begin{array}{c}\text { Step- } \\
\text { down }\end{array}$ & $\begin{array}{c}\mathbf{d} \\
(\mathbf{m}\end{array}$ & $\begin{array}{c}\text { Hor } \\
\text {.Ste }\end{array}$ & $\begin{array}{c}\text { Time } \\
\mathbf{t}\end{array}$ & $\begin{array}{c}\text { Vxy } \\
(\mathbf{m m} /\end{array}$ \\
& & $\begin{array}{c}\mathbf{z} \\
\mathbf{m})\end{array}$ & $\begin{array}{c}\mathbf{p} \\
(\mathbf{m i n})\end{array}$ & $\mathbf{m i n})$ \\
& & $(\mathbf{m})$ & & & \\
& & & & $\mathbf{m})$ & & \\
\hline Dome & 1000 & 0.5 & 5 & 1 & 53 & $\mathbf{1 0 0 0}$ \\
\hline Body & 1000 & 0.5 & 5 & 1 & 73 & $\mathbf{1 0 0 0}$ \\
\hline Fender & $\mathbf{1 0 0 0}$ & $\mathbf{0 . 5}$ & $\mathbf{5}$ & $\mathbf{1}$ & $\mathbf{4 5}$ & $\mathbf{1 0 0 0}$ \\
\hline
\end{tabular}

Choosing the step-down on the wall (wall Scallop height) and the step-down on the horizontal (bottom Scallop height) with Pro ENGINEER software are:

\begin{tabular}{lr}
\hline Types & Value $(\mathbf{m m})$ \\
\hline Wall scallop height & 0,5 \\
\hline Bottom scallop height & 0,5
\end{tabular}

The purpose of this set is to create the tool lines being equal on wall sides; the 3D curved and transition surfaces. This is great significance for the quality of the product surface.
The selection process of producing mode based on:

- Reducing speed of spindle (rpm) and forming tool $(\mathrm{mm} / \mathrm{min})$ to ensure the rigidity of the machine; 
- Model has many wall surfaces, complex 3D curved surfaces and transitions;

- Increasing step depth to $0.5 \mathrm{~mm}$ compared with the optimal mode [5] in order to reduce processing time.

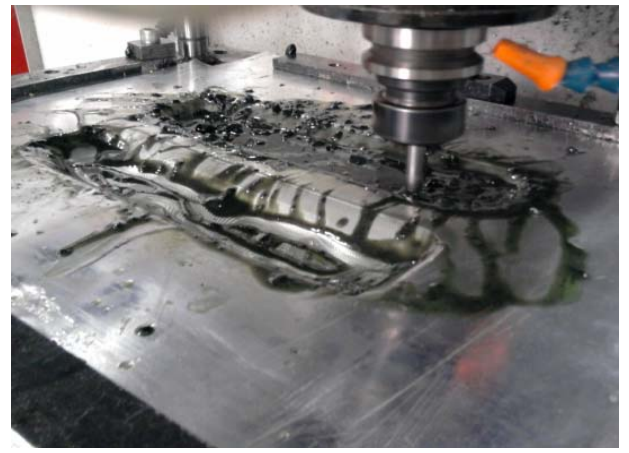

Figure 9. Forming process by TPIF

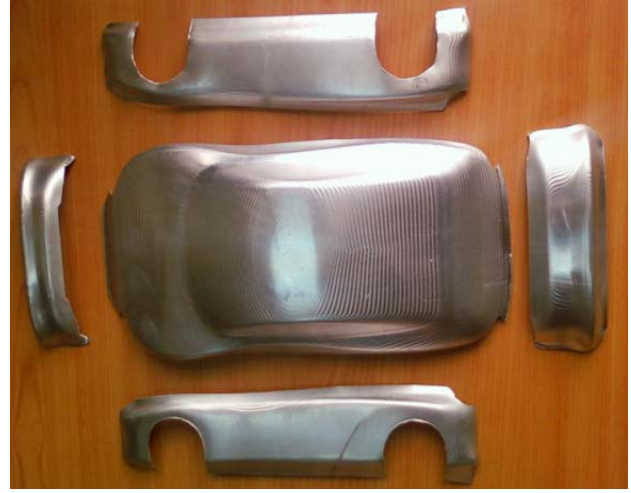

Figure 10. Components of model

\subsection{Post-processing and assembly}

After producing (Fig. 9), components are separated from the Aluminum sheet by using a cutting tool mounted on $\mathrm{CNC}$ machine (Fig. 10). After that, we polish surfaces used in the assembly; connecting parts together; then grinding the welds to ensure the aesthetic issues and durability (Fig. 11).

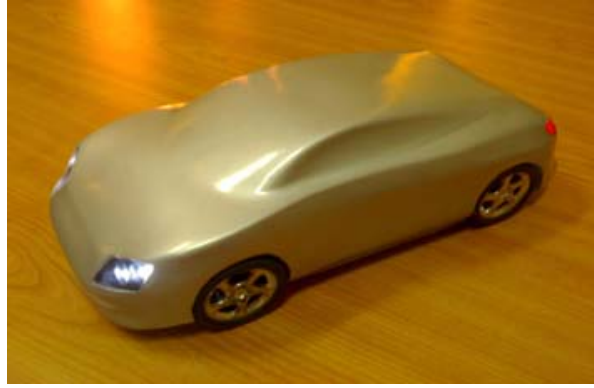

Figure 11. Complete model

\section{RESULTS}

Geometry dimension: in comparison to CAD model size, using $\mathrm{CNC}$ machines to measure some specific locations on the sample, we found that the influence of the spring-back effect, although there have been compensation in programming process, still cause a deviation of about $\pm 0.8 \mathrm{~mm}$ (Fig. 12). Such discrepancy is acceptable for the rapid prototyping process. We can improve accuracy by calculating the exact amount of compensation to fabricate gage and create a reasonable way to run appliances.

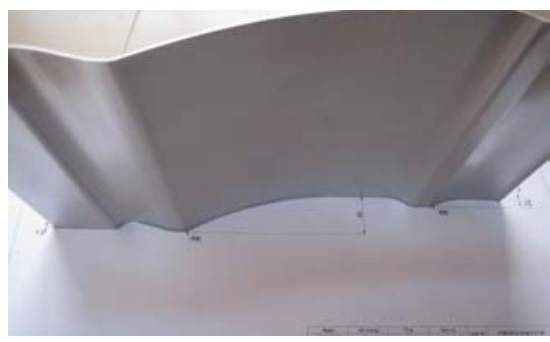

Figure 12. Checking the contour after producing

Surface quality: the theory and actual observations after processing showed that the "orange peel" phenomenon occurs in low-slope contour. This phenomenon can be over-came if the processing time increases dramatically.

The processing time: is checked and compared directly on the application software

\section{Trang 18}


in the survey process. Processing and assembling a complete car model frame require 1.5 days. If we use the stamping method to create this model, it will take a lot of time for processing which includes creating stamping mold, difficult to produce and time consuming.

Diagram comparing the advantages of two methods: ISF and stamping from level simple to complex products [5].

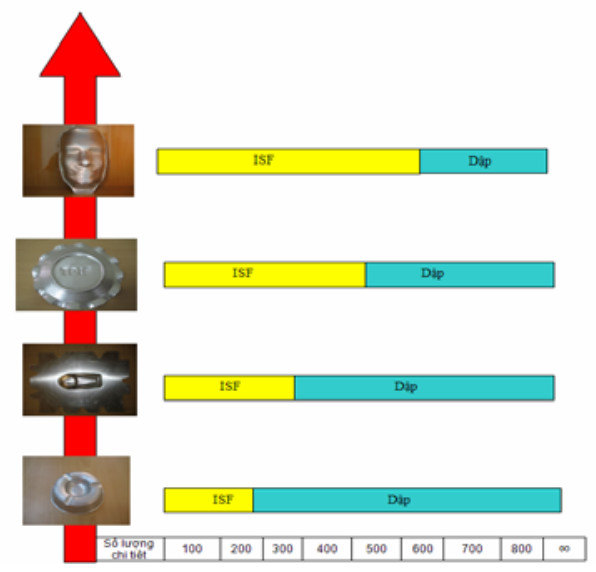

Figure 13. The comparison of cost according to the level of complexity of products between ISF and stamping [5]

ISF cost depends on the geometry and material of parts. Currently, it shows that, for moderate complex parts, the model can be easily produced with ISF. According to these calculations and observations on the chart, we can see that ISF process will be profitable if the number of products is small. If more products are required, the mass-production methods (such as stamping) will be more profitable [5].

Discussion: Investment in ISF technology will help to maintain and develop the product lines, supply chains and customers at different costs if we could uphold the competitive advantages:

- Able to implement rapid prototyping or small production series;

- The process without die;

- Quickly and easily change the size of part, enabling high flexibility;

- The process does not produce much noise.

In practical production, the process producing the product is very diverse and abundant; the process technology to create products contains many research achievements. Producing with ISF technology will bring high economic efficiency for the products, which are produced in small batch, single or rapid prototyping.

\section{CONCLUSIONS}

The article introduces a rapid prototyping sheet-type product process by ISF technology including all steps from design and process 3D CAD model, calculate and select the technological parameters, setting up manufacturing and the stage of postprocessing. The samples formed successfully showed high applicability of this technology to practical work, the complex products with the real size can be produced in industries: automotive, motorcycle, civil... and the National Key Lab. of Digital Control and System Engineering (DCSE LAB) in HCMC University of Technology has recently conducted ISF technology researches (theoretical, experimental, and application). 


\title{
ÚNG DỤNG CÔNG NGHỆ ISF GIA CÔNG MÃ̃U CHI TIẾT Vỏ Ô Tô
}

\author{
Phan Đình Tuấn, Nguyễn Thiên Bình, Lê Khánh Điền, Phạm Hoàng Phương \\ DCSELAB, Trường Đại học Bách Khoa, ĐHQG-HCM
}

TÓM TĂT: Bài báo trình bày một quy trình úng dụng công nghệ biến dạng cuc bộ liên tục (ISF) để tạo hình các sản phẩm dạng tấm với mục đích tạo mẫu nhanh hoạc sản xuất đơn chiếc, bao gồm các bước tù̀ thiết kế và xủ lý mô hình CAD 3D, tính toán và chọn các thông số công nghệ, thiết lập gia công và giai đoạn xủ lý sau gia công, có kế thùra nhiều kết quả nghiên cứu truớc đây của nhóm về ảnh hưởng của các thông số công nghệ đến góc tạo hình và chất lượng bề mặt sau gia công trong phuơng pháp ISF để làm cơ sở lựa chọn các thông số công nghệ trong quá trình tạo hình đối với tùng sản phẩm cu thể. Các mẫu sản phẩm được tạo hình thành công cho thấy tính ứng dụng cao của công nghệ này vào thực tế có thể gia công các chi tiết phức tạp với kích thuớc thật trong các nghành công nghiệp xe hơi, xe máy, dân dụng...

Keywords: SPIF, ISF, Single Point Incremental Forming, ISF real-parts, ...

\section{REFERENCES}

[1]. W.C. Emmens, G.Sebastiani, A.H. van den Boogard; The technology of Incremental Sheet Forming - A brief review of the history; Journal of Materials Processing Technology 210 (2010), p981997.

[2]. Nguyen Thanh Nam, Phan Dinh Tuan, Le Khanh Dien, et al.; Research on the forming angle of A1050-H14 aluminum material processed by using SPIF technology; Journal of Science and Technology Development - VNU-HCM, Vol. 12 pp $72-79$ (2009).

[3]. Nguyen Thanh Nam, Phan Dinh Tuan, Le Khanh Dien, et al.; Research on the finish surface quality of A1050-H14 aluminum product processed by using SPIF technology; The 2nd Vietnam
Science - Technology Conference on Mechanical Manufacturing Engineering; Hanoi 2009

[4]. Nguyen Thanh Nam, Le Khanh Dien, Phan Dinh Tuan, Nguyen Thien Binh; Book: Guide for practising the SPIF Technology; VNU-HCM Publisher; 2010.

[5]. Nguyen Thanh Nam; Final Report of the VNU-HCM Key Project 2008: Research on the Dieless Sheet Forming Technology; 2010.

[6]. Jukka Tuomi, and Lotta Lamminen ; Incremental Sheet Forming as a Method for Sheet Metal Component Prototyping and Manufacturing; 10èmes Assises Européennes de Prototypage Rapide - 14 $\& 15$ september 2004.

\section{Trang 20}

